ISSN 0206-5657. Вісник Львівського університету. Серія біологічна. 2018. Випуск 78. С. 37-44 Visnyk of the Lviv University. Series Biology. 2018. Issue 78. P. 37-44

УДК 561:582.661.15:551.4.032 (477) 626 / 627

\title{
TYPE SPECIMENS OF VERONICA (PLANTAGINACEAE) IN THE TURCZANINOW HISTORICAL HERBARIUM AT THE NATIONAL HERBARIUM OF UKRAINE (KW): A PRELIMINARY ASSESSMENT
}

\author{
D. Albach ${ }^{1}$, S. Mosyakin ${ }^{2}$, S. Antonenko² \\ ${ }^{1}$ Institute of Biology and Environmental Sciences, Carl von Ossietzky University, Oldenburg \\ D-26111 Oldenburg, Germany \\ e-mail:dirk.albach@uni-oldenburg.de \\ ${ }^{2}$ M.G. Kholodny Institute of Botany, NAS of Ukraine \\ 2, Tereshchenkivska St., Kyiv 01004, Ukraine \\ e-mail: inst@botany.kiev.ua
}

\begin{abstract}
A recent taxonomic and nomenclatural re-assessment of the Turczaninow historical collection at the National Herbarium of Ukraine resulted in identification of more than 35 type specimens of Veronica sensu lato (Plantaginaceae). The best represented collectors and authors of plant taxa are P.E. Boissier, G. Bentham, A.A. Bunge, and C.F. Ledebour; there are also some original specimens of C. Allioni, L.K.A. Chamisso \& D.F.L. Schlechtendal, P.M. Opiz, M. Tenore, P.P. Wierzbicki, and some other botanists. Most of the revealed specimens are isotypes, isolectotypes, and syntypes, but the type status of some specimens should be re-assessed. The role of the JSTOR Global Plants and other large-scale herbarium digitization projects is emphasized. The growing online availability of historical taxonomic publications is also crucial for current taxonomic research. Collections of the Turczaninow herbarium and their possible sources are briefly characterized. It is also concluded that a special project is much needed for proper preservation, digitization, and scientific assessment of the vast Turczaninow's collection, which contains numerous historical specimens (including many types) of great importance for plant taxonomy worldwide.
\end{abstract}

Keywords: Veronica, Plantaginaceae, herbarium, history of botany, plant taxonomy

\section{Introduction}

The historical herbarium collection of Nikolai S. Turczaninow (1796-1863, Николай Степанович Турчанинов in Russian, Микола Степанович Турчанінов in Ukrainian, also sometimes transliterated as Turchaninov, Turtschaninoff, Turczaninov, etc.) is now part of the National Herbarium of Ukraine (KW, Herbarium of the M.G. Kholodny Institute of Botany of the National Academy of Sciences of Ukraine). The collection comprises ca. 150000 specimens (representing ca. 53000 taxa), but their exact number is unknown, mainly because several specimens are often placed on one herbarium sheet (Shiyan, 2011). The collection was accumulated by Turczaninow during his almost lifetime activities as an amateur botanist. Despite his lack of special botanical education, Turczaninow managed to contribute greatly to plant taxonomy and described 172 genera and at least 1560 species of vascular plants, mainly from Asia, Africa, Australia, and South America, but also several species occurring in Europe and North America. The importance of Turczaninow's herbarium collection in the M.G. Kholodny Institute of Botany of the National Academy of Sciences of Ukraine and its amazing and turbulent history are outlined in several publications, mostly those in Russian or Ukrainian (Lipschitz, 1964; Myakushko, 1976; Myakushko et al., 1979; Kamelin \& Sytin, 1997, Shiyan, 2011, etc.), with only a few sources available in English (e.g., Jain, 1979; Stafleu \& Cowan, 1986; Marchant, 1990; Fryxell \& Krapovickas, 1990; (C) Albach D., Mosyakin S., Antonenko S., 2018 
Mosyakin et al., 2018, and references therein). Unfortunately, this important historical herbarium is underestimated and underused by plant taxonomists. However, this collection is amazingly rich in types and other important specimens of outstanding scientific and historical value. Due to three projects at KW supported by The Andrew W. Mellon Foundation, considerable progress has been made in digitization of specimens of the Turczaninow Herbarium, but the images and data available online through the JSTOR Global Plants website (https://plants.jstor.org/) mostly cover the taxa described by Turczaninow himself.

\section{Material and Methods}

The standard methods of herbarium taxonomy and curation were used. The specimens were digitized and databased following the protocols and formats applied by the JSTOR Global Plants (https://plants.jstor.org/) and using the HerbScan equipment and corresponding software provided to the M.G. Kholodny Institute of Botany through three herbarium digitization projects within the framework of the African Plants Initiative (API), Latin American Plants Initiative (LAPI), and Global Plants Initiative (GPI), supported by The Andrew W. Mellon Foundation. The protologues were consulted mainly using the Biodiversity Heritage Library (https://www. biodiversitylibrary.org/) and some other online resources; for some taxa, paper copies were also consulted in libraries. For comparison, available high-resolution digital images of some taxa were studied in the online collections of JSTOR Global Plants and in some herbaria.

\section{Results and Discussion}

Our preliminary taxonomic and nomenclatural re-assessment of the Turczaninow historical collection at KW resulted in identification of more than 35 type specimens (probably more, the assessment continues) of Veronica sensu lato (Plantaginaceae, formerly usually placed in Scrophulariaceae). That group was not a focus of particular taxonomic interest of Turczaninow because only two new species in the genus were described by him, but he tried to accumulate as many diverse taxa of vascular plants of the global flora as possible.

The best represented collectors and authors of plant taxa are P.E. Boissier, G. Bentham, A.A. Bunge, and C.F. Ledebour; there are also some original specimens of C. Allioni, L.K.A. Chamisso \& D.F.L. Schlechtendal, P.M. Opiz, M. Tenore, P.P. Wierzbicki, and some other botanists, mainly of the first half of the $19^{\text {th }}$ century. Most of the revealed specimens are isotypes, isolectotypes, and syntypes, but the type status of some specimens should be re-assessed. It is known that Turczaninow purchased the private herbarium of J. A. Schultes; he also obtained (through exchange and purchase) many specimens directly from other contemporary botanists (see Mosyakin et al. 2018 and references therein). Unfortunately, the archive of Turczaninow, containing letters that he received from W.S.J.G. Besser, J. Bentham, E. Boissier, A.A. Bunge, A. Gray, R.F. Hohenacker, J.D. Hooker, G.S. Karelin, C.F. Ledebour, K.F.P. Martius, C.A. Meyer, E.L. Regel, and many other outstanding botanists and other colleagues, has been lost or destroyed in Kharkiv during World War II (Shostenko, 1939; Mosyakin et al., 2018). The precise sources of many specimens in KW-TURCZ remain unknown because Turczaninow incorporated them in his main collection without indicating their provenance.

Here we provide basic information about most important and interesting selected original specimens, with brief comments, when necessary. The species below are listed alphabetically. The currently accepted names are underlined. Acronyms of herbaria follow Index Herbariorum (Thiers, 2018-onward).

Veronica acutiflora Benth. 1846, nom illeg. (non Lapeyr. ex Roem. \& Schult. 1817; =

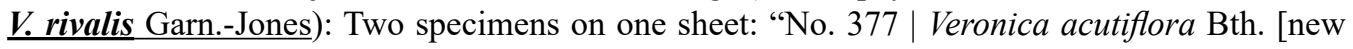
identification probably added by Schultes] | Veronica angustifolia, A. Rich. | North ${ }^{\mathrm{n}}$ Isl. | New 
Zealand | 1838 | All. Cunningham [manu Schultes?]". The second label is almost identical, with an inscription "All. Cunn. non A. Rich." added. It should be noted that A. Cunningham's types are not common in herbaria: types are found only in K and WELT.

Veronica allionii Vill. (authentic specimen?): "Veronica Allionii All. [“All.” added by Schultes] | Ex herb. Allionii | Balb. | herb. Schult.”. This is an important specimen since Villars' specimens of $V$. allionii are not considered widely distributed; the neotype is in GRM, and another possible original specimen is in MPU.

Veronica alpina L. var. unalaschcensis Cham. \& Schltdl. (= . wormskjoldii Roem. \& Schult. subsp. nutans (Bong.) Pennell): specimen 1 with the label "Veronica unalascensis Cham. \& Schlecht. | Unalachka | Kastalsky"; 2 specimens with identical labels "Veronica | Unalachka". G. Kastalsky participated with L.K.A. von Chamisso and D.F.L. von Schlechtendahl in the expedition onboard the Ryurik under the leadership of O. von Kotzebue. Another original specimen is in B.

Veronica angustata Opiz, nom. inval. (= . spicata L.): "Veronica angustata. Opiz | Cebulka. Opiz". Types of Opiz were thought to be in PR only, but the first author (Albach) also found recently a specimen in BREM. The specimen in KW is important because the name has been published without any description.

Veronica armena Boiss. \& A. Huet (syntype): "Huet de Pavillon | Plantae Orientales exsiccatae | Veronica armena Boiss. et Huet | (spec. nova) | In aridis | Ad radices montium TechDagh suprà Erzeroum. | Jun. 1853. Armenia" (printed label with handwritten identification added). Specimens of Huet de Pavillion are distributed widely; original specimens of $V$. armena are also present in BP, BM, FI, G, GOET, JE, S, W, and WAG.

Veronica aucheri Boiss. (syntype): „Veronica Aucheri Boiss. | alp. Demavend | Aucher-Eloy-Herbier d'Orient No. 5099”. Specimens of Aucher-Eloy are also widely distributed, with known types in W, WU, KW, and recently seen in OXF.

Veronica bombycina Boiss. \& Kotschy (syntype): “Th. Kotschy. Iter Syriacum 1855. In Libano ad Bscherre et circa Cedretum. | 301. Veronica bombycina Boiss. \& Kotschy n. sp. | In fissuris rupium summi Makmel alt. 8500 ped. Die 23. Jul." (printed label). Specimens of Kotschy were probably most widely distributed among specimens of other collectors for Boissier. Original specimens of $V$. bombycina are found in B, BM, BP, GH, S, W, and now in KW.

Veronica buxbaumii Ten. (original material): „Veronica buxbaumii Ten. | In arvis Neapolis | Tenore | herb. Schult.". The lectotype is in NAP, but Tenore's specimens are found in other herbaria such as M, UPS, and KW, but they are rare and the types difficult to identify and to distinguish from later collections.

Veronica caespitosa Boiss.: "Herb. E. Boissier | Veronica caespitosa Boiss. | Cadmus supra Gheyra et Olympi cacumina. aest. 1842". The specimens collected by Boissier are rarer than specimens of Aucher-Eloy and some other collectors for Flora Orientalis.

Veronica campylopoda Boiss.: 3 specimens (syntypes): specimen 1: "Veronica campylopoda Boiss. [new identification added in ink over the printed label] | 118. Veronica biloba. Vahl. | Ad radices montis Sinai locis planis in | glareosis graniticis | Unio itiner. 1835 | d. 19. Apr. leg. W. Schimper." (isolectotype); specimen 2: "Veronica campylopoda Boiss. | herb. - Boiss. | (V. biloba. Un. itin. Herb. Schimp. 1. N. 118. non Vahl) |A V. biloba Vahl. pedunculis recurvis, sepalis angustis, seminibus dimidio minoribus rugulosis diversa | In agris pinguioribus pr. Aleppam. D. 24. Apr. $1841 \mid$ Th. Kotschy. Pl. alepp. kurd. moss. 145. Ed. Hochenacker. 1843" (printed label); specimen 3: “Veronica campylopoda Boiss. | Pers. boreal. | Aucher-Eloy-Herbier d'Orient No. 5090" (syntype). Four collections were cited as syntypes; specimens of Kotschy are widely distributed (known from 12 herbaria), but Schimper's specimens are also present in 11 herbaria. 
Veronica cana Wall. Specimen 1: "Veronica cana Wall. Nepal | Wall. coll. n 401 A.”; Specimen 2: "Nepal Wallich | Veronica cana | Wall." (Syntypes). There are many specimens that originated from the Wallich herbarium in KW-TURCZ (various families). Duplicates of Wallich 401 are widely distributed in at least 11 herbaria.

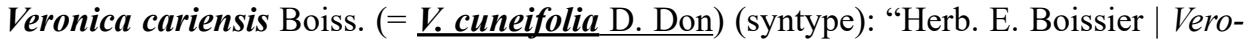
nica cariensis Boiss. | Tmolus, Cadmus supra Gheyra. Juni 1842”.

Veronica crassifolia Wierzb. ex Heuff. 1835 (non Kit. ex Roem. \& Schult. 1817): ,Veronica crassifolia Wierzbickij | (non Kitbl.)| M. Rg. [?] m. Simion [Szimcon of the protologue?] Ban. [Banat]. Aest. 1833[5? illegible]". Wierzbicki sent around many of his plants (known from 12 herbaria), but mostly after their publication. That problem is discussed by Albach et al. [2017]. If the year 1833 is correct, then the KW specimen is an isolectotype; if it is 1835 , it does not belong to original material. Veronica crassifolia is now considered a hybrid of $V$. orchidea Crantz with V. barrelieri H. Schott ex Roem. \& Schult.

Veronica densiflora Ledeb.: 3 authentic specimens (syntypes or isolectotypes?): "Veronica angustata $\mathrm{n}$. | Altai”, "Veronica densiflora | fl. alt. | Bunge", one specimen with only the name indicated.

Veronica diosmifolia R.Cunn. (isolectotype): “Veronica diosmifolia R.C. 1834 | A slender [one word illegible] shrub, 3-12 feet high $\mid$ at the head of Wycaddy \& Keri Keri | Rivers. Bay of Islands. Also at the $\mid \mathrm{S}$ head of Hokianga River. N. Zeald. 1834". The only other type material is in Kew (K). There is also one specimen of Veronica speciosa R.Cunn. from the Hokianga River area (locus classicus); however, it was collected by R. Cunningham in "Oct. 1834", while the type collection cited in the protologue was made in December 1833.

Veronica divaricata Boiss. \& Balansa 1856, non illeg., non Tausch 1821 (=V. balansae Stroh): "B. Balansa, Pl. d'Orient, 1855 | 688. Veronica divaricata, sp. nov. (Boiss.)|Village d'Alla-Dagh, à 7 lieues au NNO, de Mersina (Cilicie). | 16 mai” (printed label). Balansa's specimens are widely distributed, this collection is known in 10 herbaria.

Veronica elbursensis Boiss.: "Th. Kotschy. Pl. Pers. bor. Ed. R.F. Hohenacker. 1846.| 224. Veronica Elbrusensis Boiss. $n$. sp. | In declivibus orientem versus spectantibus m. Elbrus | supra pagum Passgala. D. 6. Maj. 1843" (printed label). Boissier thought first that this is a new species and so labeled widely distributed (at least 7 herbaria) specimens with this name. Later (in 1853) he concluded that it is not sufficiently distinct from $V$. biloba. The apparent typo on the label ("Elbrus") was corrected in the publication. Mt. Elbrus is in Russia (Greater Caucasus) whereas the specimens were collected in Iran (Mt. Elburs).

Veronica glaberrima Boiss. (= V. pusilla Kotschy) (syntype): "B. Balansa, Pl. d'Orient, 1855 | 689. Veronica glaberrima, sp. nov. (Boiss.) | Prairies humides de la région alpine du | Taurus, au-dessus de Boulgarmaden. | 16 août.” (printed label). Duplicates are known in at least 14 herbaria.

Veronica glandulosa Hochst. (syntype): "Schimperi iter Abyssinicum | Sectio secunda | 1149. Veronica glandulosa Hochst. | var. cordata | Demerki | U. i. 1842. [issued in the Unio Itinerara series in 1842] d. 14. Aug. 1838" (printed label). Duplicates are present in 8 or more herbaria.

Veronica himalensis D.Don (V. grandiflora Wall., non Gaertn.): "Nepal | Wallich | Veronica grandiflora, Wall. | V. Himalensis Don [new identification added in another hand and different ink] |7”. Other duplicates are known in K and E.

Veronica kotschyana Benth.: "No. 390. Veronica (Billarderii Vahl) | Kotschyana Bth. | In monte Tauro | Aestate 1836. legit Th. Kotschy" (printed label). There are 13 or more duplicates known. 
Veronica lanuginosa Benth. (syntype): "Herb. Ind. Or. Hook. fil \& Thomson |Veron. lanuginosa, Bth. | In libris meis omissa [text added in pencil] | Hab. Sikkim | Regio Alp. | Alt. 15-17.000 ped. Coll. J.D.H. [J.D. Hooker]". The type specimen at K (K001070359) has the same main label as the KW specimen; however, the K specimen has an additional field label "Samdong $16000 \mathrm{ft}$ | Sept 11/49", and the Samdong locality was indicated in the protologue.

Veronica macrostemon Bunge ex Ledeb. (authentic specimen?): "Herbar. Bung.|Veronica macrostemon $\mathrm{m}$. | Flor. orient. altaica. 1839 [the date of publication of the exsiccates?]" (printed label, with a handwritten identification). The name was validated in 1929, so probably this is not original material.

Veronica maddenii Edgew. ex Hook.f., nom. inval. (pro syn. V. javanica Blume): specimen 1: "Herb. Ind. Or. Hook. fil \& Thomson | Veron. Maddeni, Edgew. | Hab. Himal. Bor. Occ. | Regio alp. [crossed out] temp. | Alt. 4-7000 ped. Coll. T.T. [T. Thomson]; specimen 2: "Herb. Ind. Or. Hook. fil \& Thomson | Veron. Maddeni, Edgew. | Hab. Sikkim. Regio temp. | Alt. 4-7000 ped. Coll. J.D.H. [J.D. Hooker]". It is known that Turczaninow received some material from Kew and exchanged letters with J.D. Hooker. No specimens of $V$. maddenii are known from Kew, and the KW specimens may be necessary to support the actual synonymization with $V$. javanica.

Veronica microcarpa Boiss. (syntype): "Veronica microcarpa Boiss. | Aderbidjan | Aucher-Eloy-Herbier d'Orient No. 5096". Duplicates of this gathering are known from many herbaria.

Veronica montioides Boiss. ( . anagallis-aquatica s.1.) (syntype): “Th. Kotschy. Pl. Pers. austr. Ed. R.F. Hohenacker. 1845. | 663. Veronica (Veronicastrum) montioides Boiss. n. sp. | Circa fontes in jugo Kuh-Doschek alpis Kuh-Daëna. | D. 16. Jul. 1842”. At least 16 herbaria have this type material. It is a tiny form of $V$. anagallis-aquatica, a typical ecotype of ephemeral pools and river margins in Western Asia. However, DNA sequencing may reveal that some taxonomic recognition of that taxon is needed.

Veronica paederotae Boiss. (syntype): "Veronica paederotae Boiss. | Elamout | AucherEloy-Herbier d'Orient No. 5088". Duplicates are known from 4 herbaria.

Veronica recta Benth.: "herb. E. Boissier | Veronica recta Bth. in prodr. X p. 474 [new identification added in darker ink] | Veronica pectinata Vahl | var. pinnatifida Boiss. | Tmolus in dumosis Jun. 1842". It is an important specimen; the second specimen is found in Kew (K). The name has been used in literature as a synonym of $V$. austriaca L. ssp. jacquinii (Baumg.) Eb. Fisch. (accepted based on this specimen) and V. pectinata L.

Veronica rubrifolia Boiss. (isolectotype): "Th. Kotschy. Pl. Pers. bor. Ed. R.F. Hohenacker. 1846. | 224. Veronica (Omphalospora) rubrifolia Boiss. $n$. sp. | Circa Schah-Neschin in m. Elbrus pr. Derbend. Alt. 7000-8000'. D. 2. Jun. 1843” (printed label). Duplicates are known in 13 herbaria.

Veronica sessiliflora Bunge (isolectotype): "Veronica sessiliflora m. | Fl. alt. [Flora Altaica] | Bunge". The Bunge collection of this specimen is deposited in LE, P, and KW. The material has become important in our recent project on the identification of hybridization in Veronica subg. Pseudolysimachium using molecular markers. Sequencing DNA from herbarium specimens is starting to become important to determine the identity of rarely collected and taxonomically problematic taxa.

Veronica violaefolia Hochst. ex Benth.: "Schimperi iter Abyssinicum | Sectio secunda | 984. Veronica violaefolia Hochst. | In regione superiori montis Bachit fissuras rupium glarea | repletas incolens $\mid$ U. i. 1842. [issued in the Unio Itinerara series in 1842] d. 25. Jun. 1838" (printed label). Duplicates are known from at least 7 herbaria.

There are also several North American specimens of Thomas Nuttall, with his provisional names on labels and asterisks $\left(^{*}\right)$ by which Nuttall usually indicated his new taxa: (1) "Veronica 
*didymocarpa Nutt. | Lewis River. R. Mts. | Nuttall” and (2) “*Plagiocarpus sylvaticus Nutt. n. sp." with three specimens with labels "Ad fl. Oregon Columbia" and "Oregon", two of them with additional provisional identifications “Wulfenia?" and "Synthyris reniformis Bth. var.?". As far as we are aware, these names have never been validated.

\section{Conclusions}

During the recent decade, taxonomic and nomenclatural research was revolutionized by the successful implementation of several large-scale herbarium digitization projects, first and foremost, the JSTOR Global Plants (see above). Due to these projects, professional plant taxonomists and other researchers now have online access to images and data of millions of type specimens. That, in combination with the growing online availability of scanned protologues and other important taxonomic publications, opens new horizons for truly internationalized plant taxonomy. In particular, new electronic resources available online were crucial and indispensable for recent publications by the KW staff on taxonomy and nomenclature of the genera Chenopodium L. and Salsola L. and their generic segregates (Chenopodiaceae); Sibbaldianthe Juz. (Rosaceae), Artemisia L. and Jacobaea Mill. (Asteraceae), taxa of Caryophyllaceae, Ranunculaceae, and some other families. The present overview of type specimens of Veronica in KWTURCZ was also possible mainly due to online resources and the international collaborative projects at KW, in particular, those supported by The Andrew W. Mellon Foundation (USA, see above) and the current project on Veronica subg. Pseudolysimachium supported by the Volkswagen Foundation (Volkswagen-Stiftung, Germany). The generous support of the mentioned institutions is gratefully acknowledged. Finally, we conclude that a special project is much needed for proper preservation, digitization, and scientific assessment of the vast Turczaninow's collection, which contains numerous historical specimens (including many types) of great importance for plant taxonomy worldwide.

\section{REFERENCES}

1. Albach D. C., Pifkó D., Barina Z. Typifications and taxonomic notes for Veronica subgen. Pseudolysimachium (Plantaginaceae) based on material from the Hungarian Natural History Museum Budapest (BP) // Phytotaxa. 2017. Vol. 331. P. 35-50.

2. Fryxell P.A., Krapovickas A. The Malvaceae published by Turczaninow // Contributions from the University of Michigan Herbarium. 1990. Vol. 17. P. 173-182.

3. Jain S.K. A rich, but little known collection of Indian plants in U.S.S.R. // Journal of the Bombay Natural History Society. 1970. Vol. 67. P. 620-622.

4. Kamelin R.V., Sytin A. K. Nikolai Stepanovich Turchaninov (200 ${ }^{\text {th }}$ Anniversary) // Botanicheskiy Zhurnal. 1997. Vol. 82, No. 9. P. 123-137. [In Russian: Камелин Р.В., Сытин А.К. Николай Степанович Турчанинов (к 200-летию со дня рождения) // Ботан. журн. 1997. T. 82, № 9. С. 123-137].

5. Lipschitz S.Yu. Life and works of the outstanding Russian botanist and plant taxonomist N.S. Turczaninow (1796-1863). A report delivered at the General Session of the All-Union Botanical Society on 18 December 1963 // Botanicheskiy Zhurnal. 1964. Vol. 49, No. 5. P. 752-766. [In Russian: Липшиц С.Ю. Жизнь и творчество замечательного русского ботаника-систематика Н.С. Турчанинова (1796-1863). Доклад, прочитанный на общем собрании Всесоюзного Ботанического общества 18.XII.1963 г. // Ботан. журн. 1964. T. 49, № 5. C. 752-766].

6. Marchant N.G. The contribution of the Russian botanist Turczaninov to Australian plant taxonomy // Short, P.S. (Ed.). History of Systematic Botany in Australasia. Proceedings of a 
symposium held at the University of Melbourne 25-27 May 1988. Canberra: ASBS, 1990. Pp. 121-130.

7. Mosyakin S.L., Esser H.J., Freitag H. The holotype of Chenopodium baryosmon (Chenopodiaceae) rediscovered: just one of many type specimens from the private herbarium of Schultes, now in the Turczaninow herbarium at KW // Phytotaxa. 2018. Vol. 334. P. 49-54.

8. Myakushko T.Ya. The scientific heritage of M. S. Turchaninov // Ukrayins'kyi Botanichnyi Zhurnal. 1976. Vol. 33, No. 6. P. 647-651. [In Ukrainian: М'якушко T.Я. Наукова спадщина М. С. Турчанінова // Укр. ботан. журн. 1976. Т. 33, № 6. С. 647-651].

9. Myakushko T.Ya., Glagoleva N.G., Mel'nyk S.K. M. S. Turchaninov's herbarium collection of type specimens of new species // Ukrayins'kyi Botanichnyi Zhurnal. 1979. Vol. 36, No. 1. P. 85-90. [In Ukrainian: М'якушко Т.Я., Глаголева Н.Г., Мельник С.К. Гербарна колекція типових зразків нових видів М.С. Турчанінова // Укр. ботан. журн. 1979. Т. 36, № 1. C. 85-90].

10. Shiyan N.M. (Ed.) et al. Herbaria of Ukraine. Index Herbariorum Ucrainicum. Kyiv: Alterpress, 2011. 442 pp. [In Ukrainian, abridged reference part (pp. 393-442) in English: Шиян H.M. (ред.) та ін. Гербарії України. Index Herbariorum Ucrainicum. К.: Альтерпрес, 2011. 442 c.].

11. Stafleu F.A., Cowan R.S. Taxonomic literature: A selective guide to botanical publications and collections with dates, commentaries and types. Ed. 2. Vol. 6: Sti-Vuy. Utrecht/Antwerpen: Bohn, Scheltema \& Holkema \& The Hague/Boston: dr. W. Junk b.v., Publishers, 1986. 926 pp.

12. Shostenko N.A. A brief analysis of the archive of N.S. Turczaninow. Byulleten' Moskovskogo Obshchestva Ispytatelei Prirody. Otdel Biologicheskii. 1939. Vol. 48, No. 5-6. P. 144-147. [In Russian: Шостенко Н.А. Краткий анализ архива Н.С. Турчанинова // Бюлл. МОИП. Отд. биол. 1939. Т. 48, №. 5-6. С. 144-147].

13. Thiers B. Index Herbariorum. A Global Directory of Public Herbaria and Associated Staff. New York Botanical Garden's Virtual Herbarium. Available from: http://sweetgum.nybg.org/ science/ih (accessed 11 September 2018).

\title{
ТИПОВІ ЗРАЗКИ VERONICA (PLANTAGINACEAE) \\ В ІСТОРИЧНОМУ ГЕРБАРІЇ ТУРЧАНІНОВА НАЦІОНАЛЬНОГО ГЕРБАРІЮ УКРАЇНИ (KW): ПОПЕРЕДНЕ ОПРАЦЮВАННЯ
}

\author{
Д. Альбах ${ }^{1}$, С. Мосякін ${ }^{2}$, С. Антоненко ${ }^{2}$ \\ ${ }^{1}$ Інститут біологї̈ та наук про довкілля, Ольденбурзький університет \\ D-26111 Ольденбург, Німеччина \\ e-mail:dirk.albach@uni-oldenburg.de \\ ${ }^{2}$ Інститут ботаніки імені М. Г. Холодного НАН України \\ Національна академія наук України \\ вул. Терещченківська, 2, Київ 01004, Україна \\ e-mail: inst@botany.kiev.ua
}

\begin{abstract}
Недавнє таксономічне та номенклатурне опрацювання історичної колекції М.С. Турчанінова у Національному гербарії України привело до виявлення більш ніж 35 типових зразків Veronica sensu lato (Plantaginaceae). Найкраще представленими колекторами й авторами таксонів рослин $є$ Р.Е. Буасьє, Дж. Бентам, А. Бунге і К.Ф. Ледебур; є також оригінальні зразки К. Алліоні, Л.К.А. Шаміссо та Д.Ф.Л. Шлехтендаля,
\end{abstract}


Ф.М. Опіца, М. Теноре, П.П. Вержбицького та деяких інших ботаніків. Більшість виявлених зразків $є$ ізотипами, ізолектотипами та синтипами, але типовий статус деяких зразків має бути критично перевірений. Підкреслена роль JSTOR Global Plants та інших масштабних проектів із дигіталізації (оцифрування) гербаріїв. Дедалі більша доступність в Інтернеті історичних таксономічних публікацій також має вирішальне значення для сучасних таксономічних досліджень. Стисло охарактеризовано колекції гербарію Турчанінова та їхні ймовірні джерела. Зроблено також висновок про те, що для належних збереження, дигіталізації та наукової оцінки великої колекції Турчанінова, в якій містяться численні історичні зразки (у тому числі багато типів) вкрай важливі для систематики рослин у всьому світі, потрібен спеціальний масштабний проект.

Ключові слова: Veronica, Plantaginaceae, гербарій, історія ботаніки, систематика рослин 